\title{
UPAYA PENGEMBANGAN KAJIAN ISLAM MELALUI PENDEKATAN SEJARAH
}

\author{
M. Ardi Kusumawardana* \\ Abdul Qadri
}

\begin{abstract}
Abstrak: Tulisan ini membahas tentang dinamika studi Islam dalam berbagai pendekatan terutama dalam pendekatan sejarah atau historis dalam studi Islam. Tidak dapat dipungkiri, studi Islam belakangan telah memulai kajiannya dalam berbagai pendekatan yang pada awalnya pendekatan yang dilakukan Barat pada studi agama-agama termasuk Islam itu sendiri. Berbagai ilmuan menawarkan pendekatan yang dalam studi Islam, seperti sosiologi, antropologi, historis, bahkan psikologi. Diantara pendekatan tersebut, pendekatan historis dirasa lebih penting, sebab memahami agama tidak dapat lepas dari aspek historitas dulu ketika agama muncul, termasuk agama Islam, selain itu Islam juga memiliki perhatian yang besar terhadap sejarah, bahkan dalam kitab sucinya (al-Qur'an) mendapat dukungan dogmatis akan pentingnya mengambil pelajaran dari sejarah dari umat terdahulu.
\end{abstract}

Kata Kunci: Al-Qur'an, Pendekatan, Historis, Studi Islam, Sejarah.

\section{Pendahuluan}

Tslam seperti agama-agama lainnya memiliki dua dimensi yang tidak dapat dipisahkan, yaitu dimensi esoterik dan eksoterik. Pada dimensi esoteriknya, agama melampaui ruang dan waktu, melampaui rasionalitas, bersifat transenden dan mutlak. Sementara dalam dimensi eksoteriknya, agama berwujud dalam bentuk yang terstruktur, ada dalam ruang dan waktu, rasionalisme, terbatas, dan relatif.

Mahasiswa UIN Sunan Kalijaga Yogyakarta, email: ardialbukhori@gmail.com 
Relativitas bentuk agama (eksoterisme), membuka peluang untuk dilakukan pengkajian secara kritis, mendalam, dan rasional, sehingga nilai-nilai kebenaran yang dikandungnya dapat tersingkap dari tabir keterbatasan dan relativitasnya, serta dapat berfungsi sebagai sumber kemaslahatan dalam kehidupan manusia pada jagat raya ini. Dalam konteks ruang publik, Islam tidak bisa dilepaskan dari kesejarahannya yang dinamis dan kompleks, sehingga pembacaan terhadap Islam tidak cukup hanya dengan satu pendekatan, apalagi hanya dengan pendekatan normatif, melainkan harus dilakukan dengan pendekatan dan perspektif jamak.

Dari sudut waktu, Islam berproses dalam dua bentang waktu yang berbeda tetapi tidak dapat dipisahkan, yaitu pada masa proses tasyri' (pada masa Nabi) dan pasca proses tasyri' (sejak masa sahabat sampai masa sekarang). Islam, sebagai agama yang menjadi problem solver dalam kehidupan manusia pada dua bentangan waktu tersebut, sudah tentu menghadapi berbagai masalah yang berbeda. Ketika Islam berkembang semakin luas dan bersentuhan dengan keragaman budaya, maka problem yang dihadapi tentu semakin kompleks bila dibandingkan dengan problem yang dihadapi pada masa-masa proses tasyri. Karena itu, studi Islam tidaklah cukup hanya dengan dilakukan dengan analisi teks, melainkan harus juga dikaitkan dengan konteks yang melatarinya, baik konteks yang melatari pada saat teks yang diturunkan maupun konteks yang melatari pada saat teks yang akan diterapkan dalam waktu dan ruang yang berbeda.

\section{Studi Islam dan Ruang Lingkupnya}

Kajian Islam pada awalnya dikaji oleh kesarjanaan Muslim sendiri guna memahami ajaran agamanya. Namun di abad pertengahan kalangan Kristen melakukan kajian Islam yang awalnya didorong dari motivasi polemik perseteruan Islam dan Kristen, tidak jarah sering kali merendahkan. Tendensi semacam berkembang serius dengan minat kebudayaan dan masyarakat Asia dan Afrika yang dipahami pada abad ke-19 dan 20 sebagai latar belakang disiplin ilmu yang dikenal dengan orientalis (Nanji, 
2003:7). Sehingga Islam menjadi objek kajian sebagai bagian dari sejarah (Musyarrofah, 2012: 90) agama-agama. Tidak dapat dipungkiri, Islam termasuk agama yang mendapat perhatian besar dalam studi agama-agama, bisa dilihat di berbagai negara nonmuslim menyediakan studi Islam.

Sebelum masuk pada pendekatan studi Islam, perlu kejelasan sejauh mana Islam menjadi objek penelitian atau level-level dalam Islam. Ada berbagai ilmuan yang membuat pengelompokan tersebut, seperti Nasr Hamid Abu Zaid dalam tiga domain yakni (Nasution, 2012: 15):

Pertama, Teks asli Islam (al-Qur'an dan Hadis yang otentik). Kedua, Pemikiran Islam yakni ragam penafsiran atau pemahaman terhadap teks asli, seperti tafsir, fikih, tasawuf, teologi dan lainnya. Ketiga, Praktik yang dilakukan kaum Muslim yang muncul dari ragam latar belakang sosial, seperti Muslim di Pakistan yang tidak meletakkan tangan didada ketika salat, sedangkan di Indonesia meletakkan tangan di dada.

Atau dalam pembagian sederhana dibedakan Islam Normatif dan Historis atau dalam bahasa lain Islam wahyu dan produk budaya. Islam normatif seperti kelompok pertama dan Islam historis adalah Islam yang dipahami dan yang di praktikkan kaum Muslim di seluruh penjuru dunia, mulai dari masa Nabi Saw hingga seterusnya (Nasution, 2012: 14).

Adapun objek studi Islam adalah seluruh yang membicarakan Islam, mulai dari level / tingkat wahyu berupa nash, hasil pemikiran ulama, sampai pada praktik yang dilakukan oleh masyarakat muslim, atau dalam pembagian Charles J. Adams terbagi dalam sebelas bidang, yaitu Arab pra-Islam, Nabi Muhammad Saw, alQur'an, Hadis, Kalam, Hukum Islam, Filsafat, Tasawuf, Aliran Islam (seperti) khususnya Syi'ah, Peribadatan dan Agama rakyat (Adams, 1976: 43-49). Dalam tataran Islam historis di atas, berbagai pendekatan diperlukan dalam mengkaji Islam. Ada berbagai pendekatan yang ditawarkan dalam studi Islam, namun seluruhnya dapat dikatakan bermuara dari model pendekatan Charles J. Adams dalam studi agama, yakni: 
1. Pendekatan Normatif/ Religius (normative approach) yakni pendekatan yang didasari oleh sikap atau kerangka teologis dan religius dalam pengkaji agama (termasuk Islam) dengan tujuan mempengaruhi orang lain, yakni pendekatan; Pendekatan Misionaritas Tradisional, Pendekatan Apologatif, dan Pendekatan Simpati (irenic approach) (Minhaji, 2013: 73).

2. Pendekatan Deskriptif (descriptive approach) adalah pendekatan yang bersifat "Netral" atau selanjutnya dikenal dengan "Studi Ilmiah Agama" yang terbagi dalam tiga bagian; Pendekatan Sejarah dan Filologi, Pendekatan Ilmu-Ilmu Sosial, dan Pendekatan Fenomenologi.

Sehingga dapat disimpulkan bahwa studi Islam merupakan kajian berbagai unsur-unsur yang terdapat di dalam Agama Islam yakni wahyu (al-Qur'an dan Hadis Nabi), pemahaman teks, dan praktik masyarakat Islam. Pada tataran tersebut, Islam yang telah melewati 14 abad lebih, pemahaman Islam awal (sempurna) perlu ditelusuru dalam rangka menjawab tantangan masa sekarang bahkan yang akan datang. Pada upaya tersebut, unsur historisitas Islam merupakan unsur terpenting dalam memahami Islam dan peristiwa (historis) yang terjadi saat itu, sehingga perlu kajian Islam yang dilakukan menggunakan analisis atau pendekatan histosis atau sejarah, di samping pendekatan-pendekatan yang lain.

\section{Pendekatan Sejarah dalam Studi Islam}

Secara bahasa sejarah adalah kata (dan istilah) dalam bahasa Indonesia, walaupun jarang sekali buku yang menjelaskan asal-usul dan latar belakang kata tersebut, namun dapat dipastikan bahwa kata sejarah berasal dari kata bahasa Arab syajara yang berarti terjadi, memecah, berlanjut/berkembang, atau berasal dari kata Arab syajarah yang berarti pohon atau hutan. Syajaratun nasab berarti pohon silsilah (Cowan, 1976: 455), yang dalam bahasa Inggris disebut genealogical tree atau family tree, yakni urutan silsilah dalam satu keluarga besar. Sejarah dalam bahasa lain dikenal dengan taribi (Turki), history (Inggris), histoire (Prancis), storia (Italia), dan semua itu diyakini berasal dari bahasa Yunani yang dikenal dengan historia. 
Dalam bahasa jerman disebut historie atau geschichte (Nash, 1969: 14).

Dalam literatur Islam/Arab secara umum sejarah dikenal dengan istilah tarikh, satu istilah yang menurut Ibn Mandzur (Mandzur, 1970: 481) berasal dari kata arrakha yang berarti "menulis" atau "mencatat" dan tarikh berarti "catatan tentang waktu dan peristiwa", seorang sejarawan disebut dengan mu'arrikh, yakni " seseorang yang menulis sejarah atau ilmuwan dalam bidang sejarah". Pentingnya hal ini juga dikatakan: sejarah adalah pengetahuan tentang manusia masa lalu (Marrou, 1966: 33) atau pengetahuan yang berhubungan dengan kejadian-kejadian masa lalu, fakta-fakta yang berhubungan dengan kegiatan manusia baik sebagai kelompok sosial individu yang terekam dalam bentuk dokumen (Debove, 1991: 931), dan sering pula disebut: sejarah secara umum merupakan studi tentang manusia masa lalu, dan lebih spesifik menempatkan manusia sebagai masyarakat sosial dan bukan sebagai suatu spesis (Leff, 1971: 3). Karena itu bisa dipahami jika sejarah memberi perhatian penting terhadap dua hal utama: waktu dan peristiwa, elemen penting lainnya dalam sejarah adalah pelaku, tempat, dan sebab.

Sedangkan dalam istilah definisi sejarah atau historis di kalangan sejarawan berbeda-beda baik dari kalangan Muslim dan Barat, diantaranya sejarah merupakan suatu ilmu yang membahas tentang berbagai peristiwa yang memperhatikan unsur tempat, waktu, objek, latar belakang, dan pelaku peristiwa tersebut. (Ghazali, 2015: 71) Namun tidak sebatas di situ, sejarah tidak hanya masa lalu tapi juga menjangkau masa kini, sebagaimana kesimpulan dari pengertian sejarah oleh Akh Minhaji, berikut:

"Suatu ilmu yang berupaya memahami peristiwa seputar kehidupan manusia dan juga masyarakat bukan hanya yang terjadi pada masa lalu tapi juga masa kini dan sekaligus bisa memprediksi apa yang akan terjadi pada masa mendatang." (Minhaji, 2013: 25)

Dalam dunia Islam aspek sejarah menduduki tempat yang sentral (penting), setidaknya; Pertama, al-Qur'an mengajarkan umat 
Islam untuk mengambil pelajaran dari peristiwa-peristiwa yang terjadi umat terdahulu (Minhaji, 2013: 34). Kedua, Nabi Muhammad Saw sebagai Uswat Hasanat dalam realitas kehidupan, sehingga perlunya tulisan sirat nabawiyyah. Ketiga, urgensi sejarah dalam memahami al-Qur'an (asbab al-nuzul) dan Sunnah (asbab al-wurud). Hal itu, menegasi akan pentingnya sejarah dalam dunia Islam.

Kembali pada pengertian sejarah di atas dalam studi Islam, Akh Minhaji menambahkan bahwa pendekatan sejarah dalam studi Islam merupakan upaya sekuat tenaga memahami sejumlah peristiwa yang terkait dengan Islam (baik menyangkut ajaran ataupun realitas empiris sehari-hari) pada masa lalu, apa yang terjadi pada masa sekarang dan hubungan antara keduanya, kemudian pada gilirannya semua itu digunakan untuk menjawab persoalan yang dihadapi umat Islam sekarang dan juga masa yang akan datang (Minhaji, 2013: 78). Dengan demikian studi Islam dengan pendekatan sejarah dapat membuktikan konsistensi norma-norma agama di setiap ruang dan waktu, Islam tidak skeptis dan terkesan "romantisme".

Sedangkan Charls. J. Adams memberikan alasan, bahwa studi agama (kini dan akan datang) tidak dapat lepas dari pemahaman yang benar tentang agama pada masa awalnya (masa lalu) atau tanpa rujukan warisan agama masa lalu, karena keterikatannya dengan masa lalu maka kajian agama melalui pendekatan sejarah merupakan sebuah keniscayaan (Minhaji, 2013: 78).

Salah satu tokoh yang menawarkan kajian Islam melalui pendekatan sejarah ialah Mohammad Arkount, seorang pemikiran pos-tradisionalistik dari lima tipologi pemikir Islam yang berusaha membongkar otoritas teks, baginya teks suci dan tradisi tidak bisa dipisahkan dari historisitas, tetapi sebaliknya justru sepenuhnya terbentuk dan terbukakan dalam sejarah (Zuhdi, 2012: 133). Oleh karenanya, Arkount memberikan tanggapan positif pendekatan historis; "bahwa pendekatan historis, sekalipun berasal dari Barat, namun tidak hanya sesuai dengan warisan budaya barat saja. Pendekatan tersebut dapat diterapkan pada semua sejarah umat manusia dan bahkan tidak ada jalan lain dalam menafsirkan wahyu 
kecuali menghubungkannya dengan konteks historis (Armas, 2005: 66)

\section{Urgensi Pendekatan Historis}

Pendekatan historis ini, sangat dibutuhkan dalam kajian agama. Islam sendiri tidak dapat lepas dari historisitas yang berkembang di masyarakat ketika itu. Di samping Islam turun dalam rangka memberikan pertunjuk terhadap manusia, sehingga secara langsung bersentuhan dengan sosial kebudayaan umat manusia ketika itu. Hampir seluruh keilmuan dalam Islam selalu terikat (butuh) dengan sejarah.

Studi Islam dengan pendekatan sejarah dapat membantu masyarakat Islam untuk selalu konsisten dengan norma-norma agama sekaligus mampu menghadapi dan mengantisipasi berbagai persoalan hidup yang konkrit dan empiris dengan belajar dari umat Islam (bahkan juga selain Islam) masa silam dan masa sekarang untuk kepentingan masa kini dan masa akan datang (Minhaji, 2013: 27).

Berbagai tokoh memberikan tanggapan positif pendekatan sejarah dalam studi Islam, seperti Fazlurrahman mengatakan, pemahaman terhadap Islam tidak akan berhasil tanpa ditopang oleh pemahaman yang komprehensif dalam perspektif kesejarahannya, sekaligus menunjukkan bahwa pengetahuan sejarah menjadi alat penting dalam kajian Islam (Minhaji, 2013: 3).

Selain Itu, Ali Syari'ati menganalogikakannya seperti tokoh dalam mengkaji Islam, menurutnya dalam mengkaji seorang tokoh, yang pertama harus dilakukan adalah menguak pemikiran tokoh dimaksud melalui karya-karya tulisannya. Bersamaan dengan itu, dikaji pula biografi tokoh tersebut dalam rangka memahami, antara lain; korelasi antara ide-ide yang tertuang dalam karya-karya tulisnya dengan aktivitas kesehariannya. Dari situ bisa dilihat konsistensi antara ide pada satu sisi dengan praktik pada kehidupan sisi lain (Syari'ati, 1979: 39-69).

Berdasarkan analog di atas, ada dua hal yang harus dilakukan dalam studi Islam secara komprehensif, yakni: Pertama, mengkaji 
al-Qur'an sebagai warisan tertulis yang sekaligus menjadi sumber pokok ajaran Islam. Kedua adalah menelaah sejarah perjalanan Islam itu sendiri dengan mencermati bagaimana al-Qur'an itu dikaji, dipahami, dan dilaksanakan dalam sejarah umat sejak masa Nabi hingga sekarang.

Hal ini penting guna memberikan wawasan dalam memahami berbagai pola pemahaman sekaligus praktik ajaran al-Qur'an tersebut. Atau, mencoba memahami sejauh mana konsistensi antara ajaran normatif yang terdapat dalam al-Qur'an dengan praktik umat dalam kehidupan kesehariannya.

Terkait dengan ini, catatan Abd al-Aziz al-Duri tentang dua karya Abu Ja'far Muhammad Jarir al-Thabari cukup menarik. AlThabari, tegas Duri, menulis Jami' al-Bayan an-Ta'wil al-Qur'an dalam rangka memahami sekaligus menjelaskan kehendak Allah sebagaimana tertuang dalam al-Qur'an. Pada waktu yang ama, alThabari menulis Tarikh al-Rusul wa-l-Muluk dalam rangka memahami dan sekaligus menjelaskan fenomena tokoh-tokoh umat manusia. Dari dua karya ini kita sekaligus bisa melihat dan memahami tentang ada tidaknya jarak antara ajaran normatif alQur'an dengan praktik kehidupan para tokoh tersebut.

Sejalan dengan pemikiran Ali Syari'ati yang dikemukakan oleh John O. Voll adalah pemikiran Islam yang diajukan oleh Fazlul Rahman. Dalam upaya mengajak mereka yang menggeluti kajian Islam guna menjawab tantangan zaman, Rahman menekankan pentingnya dua aspek dasar: Islam normatif (normative Islam) dan Islam sejarah (bistorical Islam).

Umat Islam Indonesia juga telah lama memahami arti penting sejarah dalam studi Islam. Jalaluddin Rahmat, misalnya, mengatakan bahwa bidang kajian agama itu mencakup dua hal: ajaran dan keberagaman (pemahaman dan praktik ajaran agama dalam sejarah) (Rahmat, 1989: 91-96), sedangkan Amin Abdullah mengadopsi pemikiran Fazlur Rahman dengan menyebutnya normativitas dan historitas (Abdullah, 1999: 1). Namun kedua tokoh ini tidak atau belum memberi perhatian memadai menyangkut kajian-kajian sejarah, apalagi aplikasi dan implikasi 
terhadap studi Islam. Harus diakui bahwa banyak kalangan yang menyadari akan pentingnya sejarah dalam studi Islam, tetapi sedikit sekali yang memberikan perhatian cukup terhadap persoalanpersoalan sejarah itu sendiri. Akibatnya, tidak mengherankan jika banyak karya dalam studi Islam yang diklaim menggunakan pendekatan sejarah namun tidak didukung sepenuhnya oleh pengetahuan sejarah yang memadai. Karya-karya Azyumardi Azra bisa dikecualikan dari semua itu. Sebagai sejarawan dari kalangan PTAI, Azyumardi Azra bisa duduk dan sejajar dengan para sejarawan dari luar PTAI bukan hanya pada level nasional tapi juga level internasional. Namun demikian, nampaknya belum memberi perhatian memadai tentang sejarah sosial sebagai suatu pendekatan dalam studi Islam yang justru menjadi pokok dari pembahasan ini (Minhaji, 2013: 3).

\section{Catatan Akhir}

Pada kesimpulan ini, dapat dipahami bahwa pendekatan sejarah dalam studi Islam merupakan upaya sekuat tenaga memahami sejumlah peristiwa yang terkait dengan Islam (baik menyangkut ajaran ataupun realitas empiris sehari-hari) pada masa lalu, apa yang terjadi pada masa sekarang dan hubungan antara keduanya, kemudian pada gilirannya semua itu digunakan untuk menjawab persoalan yang dihadapi umat Islam sekarang dan juga masa yang akan datang (Minhaji, 2013: 26). Dengan demikian studi Islam dengan pendekatan sejarah dapat membuktikan konsistensi normanorma agama di setiap ruang dan waktu, Islam tidak skeptis dan terkesan "romantisme".

\section{Daftar Pustaka}

Abdullah, Amin. 1999. Studi Agama: Normativitas atau Historitas Yogyakarta: Pustaka Pelajar.

Adams, Charles J. 1976. Islamic Religious Tradition, dalam The Study of the Middle East: Research and Scholarship in the Humanities and the social sciences ed. Leonard Binder Toronto: Jonh Wiley \& Sosn. 
Armas, Adnin. 2005. Metode Bible dalam Studi al-Qur'an. Jakarta: Gema Insan.

Cowan, J. M. 1976. ed. A Dictionary of Modern Written Arabic. Ithaca: Spoken Languade Service.

Ghazali, Dede Ahmad. 2015. Studi Islam Suatu Pengantar Dengan Pendekatan Interdisipliner. Bandung: PT. Remaja Rosdakarya.

Leff, Gordon. 1971. History and Social Theory. New York: Anchor Books.

Mandzur, Muhammad ibn Mukarram ibn. 1970. Lisan al-'Arab, Vol 3. Beirut: Dar al-Lisan al-'Arab.

Marrou, Henri-Irence. 1966. The Meaning of History. Montreal: Palm Publishers.

Minhaji, Akh. 2013. Sejarah Sosial dalam Studi Islam Teori, Metodologi, dan Impelentasi. Yogyakarta: Sunan Kalijaga Press

Mu'ammar, M. Arfan, Abdul Wahid Hasan, dkk. 2012. Studi Islam Perspektif Insider / Outsider. Yogyakarta: IRCiSoD.

Nanji, Azim. 2003. Peta Studi Islam Orientalis dan Arah Baru Kajian Islam di Barat. Yogyakarta: Fajar Pustaka Baru.

Nasution, Khairuddin. 2012. Pengantar Studi Islam. Yogyakarta: ACAdeMIA + TAZZAFA.

Rahmat, Jalaluddin. 1989. Metodologi Penelitian Agama dalam Metodologi Penelitian Agama: Sebuah Pengantar. Yogyakarta: PT Tiara Wacana Yogyakarta.

Rey, A. et J. Rey-Debove. 1991. Le Petit Robert Dictionaire de la Langue Francaise. Montreal: Les Dictionaires Robesrt-Canada.

Ronald H. Nash, Ronald H. 1969. ed. Ideas of History. New York: E.P. Dutton.

Syari'ati, Ali. 1979. On the Sociology of Islam. Berkeley: Mizan Press. 